\title{
The Effect of Scientific Approach Towards Students' Activity and Learning Outcomes
}

\author{
Ahmad Fanani, Rusijono \\ State University of Surabaya \\ Surabaya, Indonesia
}

\begin{abstract}
This study aims at determining the effect of scientific approach to the activity and learning outcomes of fourth graders of elementary school in Hang Tuah 6 Surabaya. This research was conducted using quantitative approach with experimental research and pretest-posttest design. The subject of the study involved all students of Hang Tuah 6 Surabaya who were in their 4th grade of 2016/2017 academic year with the total number of students 42 for control class and experimental class. The results of the research were given as follows: in the student activity, the T test was gotten, the t count was equal to 5,00 ( $\left.t_{\text {count }}>t_{\text {table }}\right)$, the T test from the data of pretest dealing with the result of student learning got $t$ count which was equal to 0,01 ( $\left.t_{\text {count }}>t_{\text {table }}\right)$, the $T$ test data posttest dealing with the result of student learning got $t$ count which was equal to 2.60 ( $\left.t_{\text {count }}>t_{\text {table }}\right)$. Based on those results, the scientific approach on 4th grade students of Hang Tuah 6 Elementary school in 2016/2017 academic year could be said that it gave a pretty good influence.
\end{abstract}

Keywords-Scientific Approach, student activity and learning outcomes

\section{INTRODUCTION}

The world of education in Indonesia today continues to experience the quality of education which is shown by the change of curriculum which previously changed into the 2013 curriculum that is based on the scientific approach. This shift of the curriculum becomes an educational breakthrough in improving the quality of learners and learners, teaching materials as well as developing new paradigms on learning methodology. Improving the quality of education will produce a generation that has both competence and skills in responding to current and future demands. The changes as a result of the learning process can be shown in various forms such as changing their knowledge, understanding, attitudes and behavior as well as their skills, abilities and abilities, reaction power, and the recipient's power [1]. Education has an important role in realizing such thing because students, who have the competence and skills, are already prepared for the learning process. Social science education as part of the education has an important role in improving the quality of education through the 2013 curriculum.
Unfortunately, there are still obstacles in improving the quality of social science education especially in improving the students' ability. Some constraints faced are in the form of learning approaches used that have not accommodated students to improve their competencies. In addition, students are not yet active in learning. Moreover, teachers have always been the center of learning.

Therefore, an interactive and innovative learning approach is required here. One approach to learning that is interactive, inspirational and be able to enables learners to participate actively, is a scientific approach. According to Barringer [2] the learning process of scientific approach deals with type of a learning that guides students to think systematically and critically in an effort to solve problems in which the solutions are not easily seen.

In line with the definition above, scientific learning is a learning that guides the student activities as a scientist. The steps of learning with scientific approach are: 1) observing; 2) questioning; 3) gathering information / experiments; 4) associating / processing information; 5) communicating [3]. The scientific approach designs students to understand that information can be found from anywhere, anytime and not necessarily depending on the teacher alone.

Based on the reasons described above, the researcher wanted to apply a scientific approach during the learning process to improve student activity and learning outcomes. In order to make the learning more meaningful and meaningful, according to what Hamalik said [4], if someone has learned, there will be a change of behavior on the person, for example from not knowing to know and from not understanding to understand.

Based on the problem above, the researcher was interested to raise the title of research "The Effect of Scientific Approach Towards Students' Activity and Learning Outcomes in Grade IV of Elementary School”. 


\section{METHOD}

The method used in this research was quantitative experiment. Experimental research was used to find the effect of certain treatment against others with controlled conditions [5]

The research design used in this research was True Experimental Design, in which the main characteristic was that the samples used for the experimental group and the control group were randomly selected. Meanwhile, the design of this study was Pretest-Posttest Control Group Design, in which the research was conducted on two groups selected randomly. The first group was given the treatment (experimental group) and the other group played as the control group (without treatment).

The research design used is given as follows:

\begin{tabular}{|c|c|c|c|c|}
\hline & Group & Pretest & $\begin{array}{c}\text { Variable of } \\
\text { treatment }\end{array}$ & $\begin{array}{c}\text { Post- } \\
\text { test }\end{array}$ \\
\hline $\mathrm{R}$ & Eksperimen & $\mathrm{T} 1$ & $\mathrm{X}$ & $\mathrm{T} 2$ \\
\hline $\mathrm{R}$ & Kontrol & $\mathrm{T} 1$ & - & $\mathrm{T} 2$ \\
\hline
\end{tabular}

(Sukardi, 2003: 185)

This research was conducted at Hang Tuah 6 Elementary School Surabaya. The study was conducted in the even semester of the 2016/2017 academic year.

The population in this study involved all the fourth grade students in Hang Tuah 6 Elementary School Surabaya which amounted to two classes. Meanwhile, the sample of this study involved two classes. The number of samples of the study were 22 students for the control class and 20 students for the experiment class.

The data were collected through test and observation techniques. Test techniques were used to determine student learning outcomes. The test was differentiated into two kinds including the test before the treatment (pretest) and posttest test or the test after the treatment (posttest). In addition, observation was used to assess student activity.

Prior to the use, the test is tested first including test validity and test reliability. The validity of the test was used to determine the accuracy of the instrument against the concept being assessed so that it actually assessed what should be assessed. The validity test was calculated through the following formula:

$$
r_{x y}=\frac{N L X Y-(\Sigma X)(I Y)}{\sqrt{\left[N \Sigma X^{2}-(\Sigma X)^{2}\left\{\left[N Z Y^{2}-(I Y)^{2}\right\}\right.\right.}}
$$

Meanwhile, the reliability test was used to determine the consistency of the instruments in assessing what should be assessed. The reliability test was calculated through the following formula:

$$
r_{11}=\left(\frac{n}{n-1}\right)\left(\frac{s^{2}-\Sigma p q}{s^{2}}\right)
$$

The data analysis used in this research was sample homogeneity test, data normality test, and hypothesis test. Homogeneity test was used to find out the uniformity of samples from the same population. The sample of homogeneity test was calculated through the following formula

$\mathrm{F}=\frac{\text { varians terbesar }}{\text { varians terkecil }}$

Meanhwile, the normality test was used to determine whether the learning data was normal or not. The normality test was calculated through the following formula:

$$
x^{2}=\Sigma \frac{\left(f_{0}-f_{h^{2}}\right)^{2}}{f_{h_{2}}}
$$

The hypothesis test was used to know the influence or the effect of scientific approach towards the students' activity and student learning outcomes. The hypothesis test was calculated through the $t$ test formula as follows:

$$
t=\frac{M_{X}-M_{Y}}{\sqrt{\left.\left\{\frac{E x^{2}+Z Y^{2}}{N_{X}+N_{Y}-2}\right\} \frac{1}{N_{X}}+\frac{1}{N_{Y}}\right\}}}
$$

If the calculated $t$ result $\geq \mathrm{t}$ table, then there was a significant difference in the average activity and learning outcomes of the control group and experimental group. So, the hypothesis that scientific approaches had a positive effect towards the activity and learning outcomes of the fourth graders Hang Tuah Elementary School 6 Surabaya was accepted. Whereas, if the $t$ count $\leq t$ table, then there was no significant difference in the average of control group learning outcomes and experimental group. Therefore, such result would show that the alternative hypothesis was rejected.

\section{RESULTS AND DISCUSSIONS}

The data used in this study were taken from the test results. The test given in the form of pretest and posttest. The pretest was given before doing the teaching and learning process with a scientific approach.

Meanwhile, the posttest was given after applying social science materials by using scientific approach in the experimental class and social science learning conventionally 
in the control class. The data of the pretest and posttest score were taken from 42 students, 22 of which were in experimental class and 20 of which were in control class.

Further data about student activity and student learning outcomes in the form of cognitive aspects were obtained through the use of test instruments. Prior to the execution of the study, the instrument in the form of a test of learning outcomes was tested first. The test that included the validity test and reliability test.

\section{Test Results of Research Instruments}

The instrument type was a multiple-choice objective test which consisted of 20 questions. If the instrument had met the criteria, then the next data processing could be done.

The test results of the instrument were the following details.

\section{Validity test}

Testing the validity of the instrument was done through product moment formula with the help of Microsoft Excel 2010. From the validity test, it was obtained that the calculation results were interpreted with $\mathrm{r}$ table $=0.47$ with $\mathrm{db}$ $=\mathrm{N}-2=20-2=18$ and $5 \%$ significance level.

\section{Reliability test}

For reliability testing, the researcher used Spearman Brown formula performing one test. From the calculation of the results, it was obtained the results from $\mathrm{r}$ arithmetic $=0.88$ then compared with $r$ table $=0.296$ with a significance level of $5 \%$. Therefore, it could be concluded that the instrument used for the research was reliable because it had met the criteria count $>$ table

\section{Description of Research Data Result Pretest and posttest data of experimental group}

The results of data calculations obtained from pretest and posttest of experimental group, obtained description as follows

TABLE 2 DESCRIPTION OF PRETEST AND POSTTEST DATA OF EXPERIMENTAL GROUP

\begin{tabular}{|l|c|c|}
\hline \multicolumn{1}{|c|}{ Data } & pretest & posttest \\
\hline Jumlah nilai & 1909 & 2042 \\
\hline Nilai tertinggi & 86,77 & 92,81 \\
\hline
\end{tabular}

Based on the data in the table above, it is known that the score of the pretest in the experimental class obtained an average score of 86.77. Meanwhile, the posttest obtained average score of 92.81 . The result of the pretest average score with posttest was different 6.04 points.

\section{Pretest and posttest data of control group}

The result of the calculation of the data obtained from pretest and posttest of the control group resulted description as follows.

TABLE 3 DESCRIPTION OF PRETEST AND POSTEST DATA OF CONTROL GROUP

\begin{tabular}{l|l|l} 
Data & pretest & posttest
\end{tabular}

\begin{tabular}{|l|c|c|}
\hline \multicolumn{1}{|c|}{ Data } & pretest & posttest \\
\hline Score & 1734 & 1755 \\
\hline Highest score & 86,70 & 87,75 \\
\hline
\end{tabular}

Based on the above data, the description of both pretest and posttest data are presented as follows.

TABLE 4 DESCRIPTION OF THE AVERAGE VALUE OF

\begin{tabular}{|l|c|c|}
\multicolumn{1}{c}{ PRETEST AND POSTTEST DATA } \\
\hline Class & pretest & posttest \\
\hline Control class & 86,77 & 92,81 \\
\hline $\begin{array}{l}\text { Experimental } \\
\text { class }\end{array}$ & 86,70 & 87,75 \\
\hline
\end{tabular}

Based on the above table, the average pretest score achieved by the experimental class was 86.77 with the average posttest score of 92.81. Meanwhile, the average score of the pretest for the control class that was equal to 86.70 with the average score of the control class posttest was equal to 87.75 .

Based on the achievement of the average score achieved by the experimental class, between pretest and posttest had increased from 86.77 to 92.81 . For the control class, the average achievement of the score between the pretest and posttest changed from 86.70 to 87.75 .

When they were compared, the average pretest score between the experimental group and the control group, then the average yield score was not really different. Meanwhile, on the posttest score, the mean of the posttest score between the experimental class and the control class was different. The experimental group got an average score of 92.81 while the control group got an average score of 87.75 . The experimental group excelled 6.04 points from the control group's average results.

\section{Data Analysis of the Research Results Test the normality of learning outcomes}

Normality test was one part of the test requirements data analysis. The data normality test was needed to determine whether the pretest and posttest data of the control group and the experimental group were normally distributed or not. In this research, the normality test used was with Chi-Square formula.

The rule used in the normality test was that if the value $\mathrm{x} 2$ count $\leq \mathrm{x} 2$ table then the data was normally distributed. Conversely, if the count value $>$ table then the data was not normally distributed.

Based on the results of normality testing of the research data, obtained pretest normality test results of the experimental class and control class are obtained as follows:

TABLE 5 RESULT OF PRETEST NORMALITY TEST

\begin{tabular}{|c|c|c|}
\hline Class & $\boldsymbol{x}^{2}$ count & $\boldsymbol{x}^{2}$ table \\
\hline $\begin{array}{c}\text { Experimental } \\
\text { class }\end{array}$ & 6,17 & 11,07 \\
\hline Control class & 0,09 & 11,07 \\
\hline
\end{tabular}


Based on the above table, it is known that the result $\mathrm{x} 2$ count was smaller than $\mathrm{x} 2$ table for 0.05 significance level and $\mathrm{dk}=5-1=4$. Thus, it could be concluded that the pretest result data of the experimental class and the control class tested was normally distributed. Meanwhile, the posttest normality test results for the experimental class and control class, the following results are obtained:

\begin{tabular}{|c|c|c|}
\multicolumn{1}{c|}{ TABLE 6 RESULT OF POSTEST NORMALITY TEST } \\
\hline Class & $\boldsymbol{x}^{2}$ count & $\boldsymbol{x}^{2}$ table \\
\hline $\begin{array}{c}\text { Experimental } \\
\text { class }\end{array}$ & $-21,85$ & 11,07 \\
\hline Control class & 4,45 & 11,07 \\
\hline
\end{tabular}

Based on the table above, it is known that the result $\mathrm{x}^{2}$ count was smaller than $\mathrm{x}^{2}$ table for 0.05 significance level and $\mathrm{dk}=5-1=4$. Thus, it could be concluded that the posttest result data of the experimental class and the control class tested was normally distributed.

\section{The normality test of the student activities}

Student activity normality test used here was Chi Square test. The test criteria dealt with the data derived from the subjects. It was normally distributed if the chi square value of the count was smaller or equal to the chi squared table value ( $\mathrm{x}^{2}$ count $\leq \mathrm{x}^{2}$ table) and is not normally distributed if the chi square value of the count was greater than the chi square table count $\left(x^{2}\right.$ count $>x^{2}$ table $)$.

\begin{tabular}{|c|c|c|}
\multicolumn{1}{c}{ TABLE 7 RESULT OF POSTEST NORMALITY TEST } \\
\hline Class & $\boldsymbol{x}_{\text {count }}^{2}$ & $\boldsymbol{x}_{\text {table }}$ \\
\hline $\begin{array}{c}\text { Experimental } \\
\text { class }\end{array}$ & 5,27 & 7,82 \\
\hline Control class & 2,00 & 7,82 \\
\hline
\end{tabular}

Based on the table above, it is known that the result of $\mathrm{x}^{2}$ count was smaller than $\mathrm{x}^{2}$ table for signification level 0,05 and $\mathrm{dk}=4-1=3$. Thus, it could be concluded that the student activity data of the experimental class and the control class tested was normally distributed.

\section{The homogeneity test of learning outcomes}

Homogeneity tests were performed to test the uniformity of the sample samples from the same population. Testing homogeneity in this study was taken from data of the pretest results with the calculations using the formula-F test. The sample was declared homogeneous if $\mathrm{F}$ count $<\mathrm{F}$ table. Further details can be seen in the following table. TABLE 8 PRETEST HOMOGENEITY TEST RESULTS

\begin{tabular}{|c|c|c|c|c|c|}
\hline Class & $\boldsymbol{N}$ & Variance & Dk & $\mathbf{F}_{\text {count }}$ & $\mathbf{F}_{\text {table }}$ \\
\hline $\begin{array}{c}\text { Experimental } \\
\text { class }\end{array}$ & 22 & 55,07 & 21 & 1,17 & 2,15 \\
\hline Control class & 20 & 49,75 & 19 & & \\
\hline
\end{tabular}

Based on the table above, it was known that the value of Fcount of 1.17 was smaller than the Ftable value of 2.15 with a significance level of 0.05 . Thus, it can be said that the pretest of the experimental class and the control class had the same or homogeneous variance.

TABLE 9 POSTTEST HOMOGENEITY TEST RESULTS

\begin{tabular}{|c|c|c|c|c|c|}
\hline Class & $\boldsymbol{N}$ & Variance & $\mathbf{D k}$ & $\mathbf{F}_{\text {count }}$ & $\mathbf{F}_{\text {table }}$ \\
\hline $\begin{array}{c}\text { Experimental } \\
\text { class }\end{array}$ & 22 & 55,07 & 21 & 1,23 & 2,15 \\
\hline Control class & 20 & 49,75 & 19 & & \\
\hline
\end{tabular}

Based on the table above, it was known that the value of $\mathrm{F}$ arithmetic of 1.23 was smaller than the value of $F$ table of 2.15 with a significance level of 0.05 . Thus, it could be said that the experimental class posttest and the control class have the same or homogeneous variants.

\section{Test homogeneity of student activity}

The homogeneity test of student activity is done by using F-test. The subjects of the study were said to have homogeneous variants when Fcount is less than Ftable at a significant level of 5\%. Metaphysically written Fcount $<$ Ftable on the degrees of freedom (dk) of the numerator (largest variant) and degrees of freedom (dk) denominator (smallest variant).

TABLE 10 RESULTS OF POSTTEST HOMOGENEITY TEST

\begin{tabular}{|c|c|c|c|c|c|}
\hline Kelas & $\boldsymbol{N}$ & Varian & Dk & $\mathbf{F}_{\text {hitung }}$ & $\mathbf{F}_{\text {tabel }}$ \\
\hline Eksperimen & 22 & 55,07 & 21 & 1,11 & 2,09 \\
\hline Kontrol & 20 & 49,75 & 19 & & \\
\hline
\end{tabular}

Based on the above table it is known that the value of Fhitung of 1.11 is smaller than the F table value of 2.09 with a significance level of 0.05 . Thus it can be said that the student activity data of the experimental class and the control class have the same or homogeneous variants.

\section{Hypothesis testing}

After testing the normality and homogeneity, the next step is to test the hypothesis. Hypothesis testing is done by using $\mathrm{t}$ test. Hypothesis test is needed to know whether scientific approach has significant effect to activity and result of student learning of fourth grade of elementary school especially in experiment class.

To test the hypothesis used t test for pretest data of control class and experiment class. To test the hypothesis used $\mathrm{t}$ test at the significance level of $5 \%$ with $\mathrm{db}=\mathrm{N} 1+\mathrm{N} 2-2$, while the criteria is if arithmetic $\geq$ table then Ho rejected Ha accepted, If arithmetic $\leq$ table then Ho accepted Ha rejected.

From result of calculation by using $t$ test for posttest data of control group and experiment group obtained count value $=$ 0,01 from distribution table " $\mathrm{t}$ " for $5 \%$ significance level obtained table $=2.021$ at $\mathrm{db}=40$. This shows $\mathrm{t}$ count $<\mathrm{t}$ table, so it can be concluded that there is no difference in the average learning outcomes between the experimental class and 
control class before treatment is given or Ho is accepted and Ha is rejected.

While from result of calculation by using $t$ test for posttest data of control group and experiment group obtained $t$ arithmetic $=2,60$ with $\mathrm{db}=40$ and significant level 5\% obtained $t$ table $=2,021$. This shows $t$ count $>t$ table, so it can be concluded that there is difference of mean of learning result between experiment class and control class after given treatment or Ho accepted and $\mathrm{Ha}$ rejected. Thus there is a significant difference between the learning class using the saintifk approach over the control class using conventional learning.

While for student activity obtained by result of t test of experimental class and control class obtained $t$ count $=5,00$ While with $\mathrm{db}=40$ and significant level $5 \%$ obtained $\mathrm{t}$ table $=$ 2,021. This matter shows $\mathrm{t}$ count $>\mathrm{t}$ table, so it can be concluded that there is a difference in the increase of student activity between the experimental class and control class after being given treatment or Ho is rejected and Ha accepted. Thus there is an increase in the activity of class students whose learning uses a scientific approach than the control class that uses conventional learning.

\section{Discussion of Research Results}

Based on the description and analysis of data above research results indicated that:

1. Based on the data descriptions of the results of the research above showed that the average pretest in the control group and experimental group was not much different. It was possible because both groups had not been treated. Meanwhile, on the average posttest in both groups, there were differences. The average experiment group was higher than the control group average. It was because both groups were given different treatment. The group given treatment using a scientific approach found better in the results when compared to the group without using such method.

2. Before conducting hypothesis testing, the researcher performed sample homogeneity test and data normality. The sample of homogeneity test was taken from the pretest data. Homogeneity test results showed that both groups came from a homogeneous sample. Then, for normality test, the data used pretest and posttest data for both groups. The calculation results showed that the pretest data in the control group and the experimental group was normally distributed. For posttest data, both groups showed the same result of normal distribution.

3. After doing the homogeneity test and normality test, the next step was to test the hypothesis. The result of hypothesis test conducted by $t$ test formula showed that there was difference of the mean of learning result between the control group and experiment group in which the average score of the experiment group is higher than the control group. In addition, the $t$ test results also showed a difference in the average student activity between the control group and experimental group in which the average experiment group was higher than the control group.

4. Therefore, the hypothesis stating that the scientific approach had a positive effect towards the student activity and student achievement in grade 4 of Hang Tuah 6 Elementary school Surabaya was accepted.

5. Based on the above description, it could be said that this research was in line with the previous research on the use of napier bone media, among others:

a. The first relevant research was the one conducted by Saputro (2015). The results of this study states that the scientific approach can improve students' creative thinking ability. This study resulted in the conclusion that the scientific approach has an effect on the students' creative thinking ability so that the scientific approach can improve student learning outcomes.

b. Another relevant study was conducted by Maemunah (2014) under the title Educational Activity Improvement Using Scientific Approach at SD Class 1 Ketapang. This study discusses the scientific relationship to the activities of learners in learning. This study resulted in the conclusion that scientific approach influenced student activity so that scientific approach can increase student activity and make learning become meaningful and fun.

c. The third relevant research under the title The Influence of Implementation of the Scientific Approach to the Motivation of Learning and Learning Result of Indonesian Language in Primary School which was done by I.N. Sumayasa et al (2013). This study discusses the scientific relationship to learning motivation and learning outcomes. This study resulted in the conclusion that the scientific approach influences the motivation of learning as well as student learning outcomes.

\section{CONCLUSION}

Based on the results of research and data analysis, it could be concluded that the scientific approach had a positive effect towards the activity and learning outcomes of the fourth graders of Hang Tuah 6 Elementary school Surabaya. It could be seen from the result of the $t$ test which showed that there was difference of the average value between control group and experiment group.

When the hypothesis was analyzed using the $t$ test, it was found that the value of $t$ arithmetic obtained was greater than $t$ table with $5.00>2.02$. From the results of the percentage analysis and t test, it could be seen the difference of student activeness between experimental class and control class. Therefore, it can be said that the experimental class received learning with a scientific approach had more activities than the control class that accepted conventional learning.

In addition, through the hypothesis analysis using t test, it was found that the $t$ value of pretest obtained was smaller 
than the $\mathrm{t}$ table with $0.01<2.02$. Therefore, it could be concluded that there was no significant effect before it was being treated. Furthermore, the result of the $t$ test analysis of the posttest data found that the $t$ value obtained was bigger than the $t$ table $2,60>2.02$. Hence, it could be concluded that there was positive influence on result of experiment class in terms of the student learning after being given treatment in the form of scientific approach.

\section{REFERENCES}

[1] N. Sudjana, "Ibrahim. 1989," Penelit. dan Penilai. Pendidik.

[2] Y. Abidin, Desain sistem pembelajaran dalam konteks kurikulum 2013. Refika Aditama, 2014.

[3] T. Penyusun, "Peraturan Menteri Pendidikan dan Kebudayaan Nomor 69 Tahun 2013 Tentang Kerangka Dasar dan Struktur Kurikulum Sekolah Menengah Atas/Madrasah Aliyah," Jakarta: Kemdikbud, 2013.

[4] O. Hamalik, "Perencanaan Pengajaran Berdasarkan Pendekatan Sistem. Jakarta: Bumi Aksara..(2008)," Perenc. Pengajaran Berdasarkan Pendekatan Sist., 2003.

[5] Sugiyono, Metode Penelitian Kuantitatif, Kualitatif dan $R \& D$. Bandung: Alfabeta, 2012.

[6] Suharsimi,Arikunto, Manajemen Penelitian. Jakarta: Departemen Pendidikan dan Kebudayaan P2LPTK,1989.

[7] Badan Pengembangan Sumber Daya Manusia Pendidikan dan Kebudayaan dan Penjaminan Mutu Pendidikan, Depdikbud, Materi Pelatihan Guru Implementasi Kurikulum 2013 Tahun 2014 SD Kelas 1. Jakarta: Depdikbud,2014.

[8] Susan, Bawn, The Effects of Cooperative Learning on Learning and Engagement. Washington: A Project Submitted to the Faculty of The Evergreen State College, 2007.

[9] M, Dalyono, Psikologi Pendidikan. Jakarta: PT. Rineka Cipta, 2005.

[10] Robin, Fogarti,TheMindful School: How To Integreted The Curicula. Illinois: Skylight Publishing,1991.

[11] Rudy, Gunawan, Pendidikan IPS: Filosofi, Konsep, dan Aplikasi. Bandung: Alfabeta, 2011. 